\title{
高性能，低消費電力を目指す \\ CMOS デバイス構造の今後の発展* \\ Future Evolution of CMOS Devices Targeting on High-performance and Low Power
}

\section{大路 譲}

Key words High-k gate dielectrics, metal gate, gate stack, HfSiON, Fermi level pinning

\section{1. は じめに}

電子デバイスおよびそれを用いた電子機器の市場の拡大 は，Mooreの法則を指導原理とし，ITRSロードマップを 道標として進んできた。この間, 日本の半導体メーカーが 全盛を謳歌したDRAM ビジネスの時代から，市場環境， 製造技術・装置の環境は大きく変わり, 半導体産業は資金 とビジネスコンセプトをもつ者が自由に参入できる事業領 域に移ってきた。一方, 素子の微細化の進展は, 物理的に これまでにない高い障壁に直面している，LSI の製造にお いて制御すべきデバイス各部の寸法は物理現象の素過程に 関わる物理量の大きさに近づいており，1 チップに集積さ れたトランジスタの数は十億個を優に超えて, 統計物理の 見方を取り入れた製造技術の開発が必要とされている。こ のような物理限界に挑戦するデバイスの開発拉よび製造に 掛かるコストは, Moore の法則を支えてきたチップコス トの一律的な低減を難しくし, 半導体産業そのものの有り 方が問われるに至っている。

このように素子の微細化に陰りが見え始めた昨今, Moore の法則に頼らない More than Moore, すなわち, MOSトランジスタの微細化に頼っていたロジックやメモ リといった大規模集積回路にアナログ, 高周波, 高耐圧, パワー，センサー，等のデバイスを集積することにより新 たな市場の拡大を図り，引き続き半導体産業の拡大を図っ ていこうという考え方も議論され始めている。また $\mathrm{Si}^{-}$ CMOS に替わる微細化, 高性能化, 高集積化を担うデバ イスの探求も進められている.

しかしながら、これまでの Si-CMOS 微細化による高集

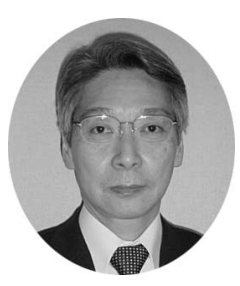

*原稿受付 平成 20 年 3 月 26 日

*(株) 半導体先端テクノロジーズ（荻城県つくば 市小野川 16-1)

大路 譲

1977 年東京大学大学院工学系研究科修士課程卒 業. 同年(株)日立製作所入社. 2003 年(株)ルネ サステクノロジに転籍. 2006 年(株)半導体先端 テクノロジーズに出向. CMOS フロントエンド プロセスの開発に従事し，現在に至る。
積化の速度は 3 年で 2 倍と恐ろしいほど早く, 新規デバイ スを $\mathrm{Si}-\mathrm{CMOS}$ の完成レベルにまで引き上げるに十分な時 間はない，そこで新規デバイスの開発を進める一方で, $\mathrm{Si}-\mathrm{CMOS}$ の極限に向かった微細化を突き進めることが最 重要な課題となっている.

近年, 日本の半導体産業の世界市場に扔ける地盤沈下が 喧伝されているが, 上記のような技術, 事業, 両面での半 導体産業の質的転換の時期は, 日本の半導体産業が再度世 界のリーダーになるチャンスともいえる.

本稿では, hp $45 \mathrm{~nm}$ 以降の Si-CMOS デバイスの微細化 に扔いて, トランジスタの微細化と性能向上を実現してゆ くためのフロントエンドプロセス技術に焦点を絞って現状 を概説する。

\section{CMOS 微細化のトレンド : ブースター技術}

ITRS (International Technology Roadmap for Semiconductors）ロードマップ11 は 15 年先を見た半導体 産業の主要動向予測を行い, 半導体研究開発の有効な指針 にしょうと, ヨーロッパ・日本・韓国・台湾・米国の 5 地 域の専門家が参加, 作成しているものである. 2007 年 ITRS ロードマップによる微細化トレンドでは, 微細化の 先頭を走るフラッシュメモリの $45 \mathrm{~nm}$ 技術が 2008 年, 32 $\mathrm{nm}$ 技術が 2011 年, $23 \mathrm{~nm}$ 技術が 2014 年, $16 \mathrm{~nm}$ 技術が 2017 年となっており, DRAM と MPU がそれに 2 年遅れ て続いている.

MPU を構成するロジックトランジスタは, その性能 (オン電流とオフ電流) から, High Performance (HP), Low Operation Power (LOP), Low STandby Power (LSTP) の三つに分類して議論されている. ITRSでは, 重要な性能指標として速度性能 ( C ・ V dd / Ion), 動作時電 力 $\left(\mathrm{C} \cdot \mathrm{Vdd}^{2}\right)$, 待機時電力 (Ioff), のロードマップを策 定している. $90 \mathrm{~nm}$ ノードまでの CMOS デバイスはこれ らのロードマップを実現するために Dennard のスケーリ ング則 ${ }^{2}$ に沿ったゲート長の縮小により，上記指標性能を 達成してきた。しかし， $65 \mathrm{~nm}$ ノード以降の微細化に対し てはゲート長の縮小だけでは十分な性能を得ることが難し 


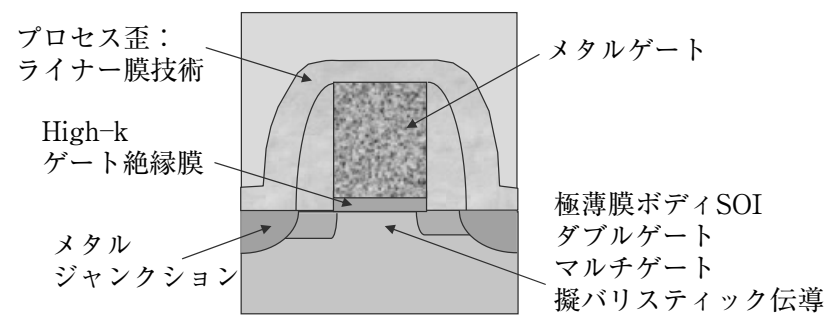

図 $145 \mathrm{~nm}$ ノード以降, MOS トランジスタ構造の各部に導入が予 想されるテクノロジブースタ技術

くなっている. 具体的には, オン電流, 短チャネル効果抑 制，消費電力低減などの要求項目すべてを CMOS のスケ ーリングだけで達成することが困難な状況にある。 スケー リングに伴って増大するプロセスのばらつき，例えば，寸 法のグローバル，ローカルなばらつき，不純物濃度，組 成, 結晶性, 欠陥密度のゆらぎ, 局所応力, 歪のゆらぎ, などは，Vth，移動度，抵抗，容量，等のデバイス特性を ばらつかせ，スケーリングそのものを難しくしている。そ こで，ゲート長縮小以外のトランジス夕性能向上策とし て，テクノロジーブースター ${ }^{3)}$ と呼ばれる幾つかの方法が 検討されている. $45 \mathrm{~nm}$ ノード以降, MOS トランジスタ 構造の各部に導入が予想される技術を図 1 に示した。同 図に示した技術の中でチャネルに歪を加えて実効移動度を 向上させる技術は，既に $65 \mathrm{~nm}$ ノードから全面的な実用化 の段階に入っている。始めに， $\mathrm{Si} / \mathrm{SiGe}$ 層の格子定数の違 いを利用した歪 $\mathrm{Si}$ 基板の 2 軸性歪による電子および正孔 の移動度向上の研究が進められたが，2003 年ごろに，高 い内部応力をもつ絶縁膜をゲート上に重ねる方法，あるい はソース/ドレイン領域に $\mathrm{SiGe}$ 層を成長させる方法などの 外部からの応力印加による 1 軸性のチャネル歪印加方法 (プロセス歪) が相次いで提案された ${ }^{4) 5)}$. これによりチャ ネル歪の実用化が急速に進んだ。2007 年に Intel 社が発表 したCMOS デバイスでは，これらの歪導入技術を駆使し て, NMOSのオン電流で $1.36 \mathrm{~mA} / \mu \mathrm{m}$, PMOS で 1.07 $\mathrm{mA} / \mu \mathrm{m}$ と非常に高い值を達成している ${ }^{6)}$.

次いで実用化が検討されているのが High-k/メタルゲー 卜技術であり，次章で詳細な議論をする。それ以外の，極 薄膜ボディ SOI，ダブルゲート，マルチゲート，擬バリス ティック伝導，等のブースター技術については，各研究機 関，各デバイスメーカーにおいて研究開発が進められてい るが，トランジス夕の構造，プロセスが大きく変わると考 えられることから，実用化は現状の CMOSトランジス夕 の微細化極限を追及した後になるだろうと考えられる。

\section{High-k/メタルゲート}

\section{1 ゲートスタック構造}

2007 年末に High-k/メタルゲートを搭載した Intel 社の CMOS 製品が市場に投入され，この技術も既に実用化競 争の段階に入ったといえる。混乱を避けるために注意をし ておくと，同社はこの技術を $45 \mathrm{~nm}$ Logic Technology と
表現しているが，技術の内容はITRSロードマップの 2007 年のいわゆるハーフピッチ $65 \mathrm{~nm}$ 技術に相当するも のであり，ITRS2005で予測してきた通りのスケジュール で High-k 膜の実用化を達成したことになる

2000 年代に入り，これまで使用してきた SiON ゲート 絶縁膜の薄膜化限界が現実味を帯びるに至って, 高誘電率 材料，いわゆる High-k ゲート絶縁膜の開発に拍車が掛か った。当初は $\mathrm{Zr}_{2} \mathrm{O}_{5}, \mathrm{Ta}_{2} \mathrm{O}_{5}, \mathrm{TiO}_{2}, \mathrm{Al}_{2} \mathrm{O}_{3}, \mathrm{HfO}_{2}$, 希土 類酸化物等多くの High-k 膜が候補となったが，現時点で は Hf 酸化物系の High-k 膜が主流になった。 High-k 膜に 対する諸要請は，実効酸化膜厚（EOT）を $1 \mathrm{~nm}$ 以下にま で低減（スケーリング）できること，リーク電流を $\mathrm{SiO}_{2}$ 比で 3〜4桁低減できること，比誘電率が 10 (長期的には >20）以上であること, $\mathrm{SiO}_{2}$ に匹敵するキャリア移動度 を実現できること，CMOSのしきい值電圧（Vth）を０V 近くまで制御できること, CMOSの電気特性において $\mathrm{SiO}_{2}$ と同等の低ばらつきを実現できること, 特性の安定 性・再現性に優れていること，10 年の信頼性を保証でき ること，等である。これに対し隘路となったのは，Si と $\mathrm{HfO}_{2}$ との界面で生ずる酸化還元反応により発生する酸素 空孔などが原因となって，フェルミレベルがミッドギャッ プ付近に固定化されてしまい，MOSトランジスタのしき い值が制御できない現象（Fermi Level Pinning）である. 2003 年に Hobbs 等 ${ }^{7}$ が多結晶 $\mathrm{Si}$ 電極と $\mathrm{HfO}_{2}$ 膜あるいは $\mathrm{Al}_{2} \mathrm{O}_{3}$ 膜の界面に生ずる欠陥に起因する Fermi Level Pinning 現象のモデルを提案し，この現象が避けがたい本 質問題として捉えられるようになった. Shiraishi 等 ${ }^{8}$ は $\mathrm{HfO}_{2}$ から $\mathrm{Si}$ への酸素移動による酸素空孔の発生と電子の 移動でこの現象に対するモデルを提示した。この現象を回 避するため, 多結晶 Si に代え金属電極を採用することが 有効であるが, フラットバンド電圧 Vfb の変動は電極/ High-k 膜界面の現象だけでは説明しきれない。Toriumi 等 ${ }^{9)}$ は, もう一つの界面である High- $\mathrm{k}$ 膜 $/ \mathrm{SiO}_{2}$ 界面での現 象に注目し，HfLaOx 膜中の La 組成を膜厚方向に精密に 制御した実験で，High-k 膜/ $\mathrm{SiO}_{2}$ 界面でのダイポールの 存在を示し，このダイポールによってVfbの值が決まっ ていることを主張している。これらの結果から, High-k ゲート絶縁膜採用に当っては金属電極を用いるとともに， High-k 膜/ $\mathrm{SiO}_{2}$ 界面を制御する技術が必要と考えられる。

金属電極では多結晶 $\mathrm{Si}$ のように不純物ドーピングによ り仕事関数を変えることができないため, PMOS, NMOS に異なる仕事関数をもつ金属電極を用いねばならない.ゲ ート電極/ゲート絶縁膜の構造をゲートスタック構造と呼 び，図 2 に示す以下の構造が提案されている. (1) 2 種類 の金属電極を 1 種類の High-k 絶縁膜上に形成する（Dual Metal Gate/Single High-k=DMSH)，(2) 2 種類の金属電極 を 2 種類の High-k 絶縁膜上に形成する (Dual Metal Gate/Dual High-k=DMDH), (3) 1 種類の金属電極を 2 種 類の High-k 絶縁膜上に形成する (Single Metal Gate/ Dual High-k=SMDH), (4) 2 種類の金属シリサイドを 1 種 


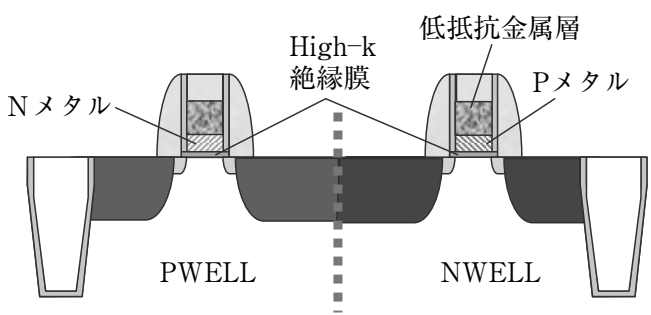

(1)Dual Metal Gate/Single High-k= DMSH)

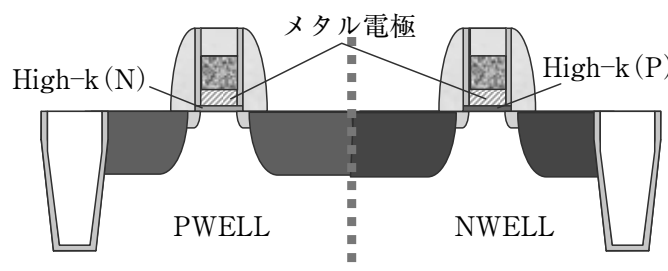

(3) Single Metal Gate/Dual High- $\mathrm{k}=\mathrm{SMDH}$ )

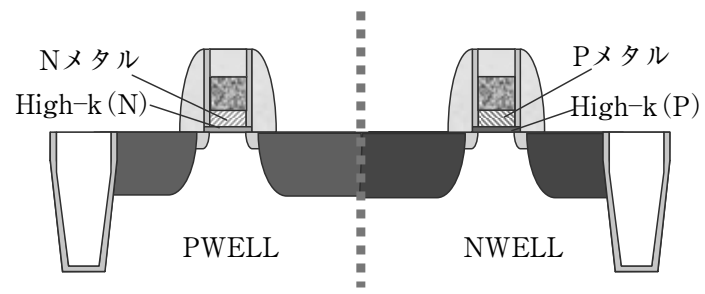

(2)Dual Metal Gate/Dual High-k= DMDH)

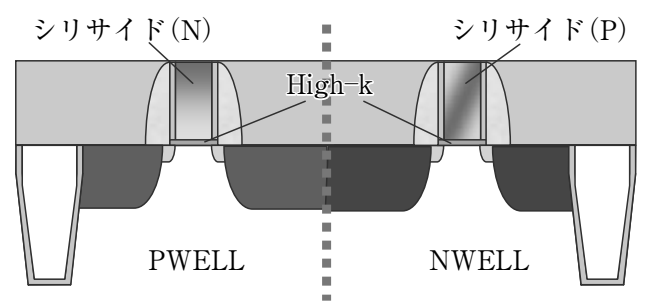

(4)Full Silicide Gate

図24種のゲートスタック構造

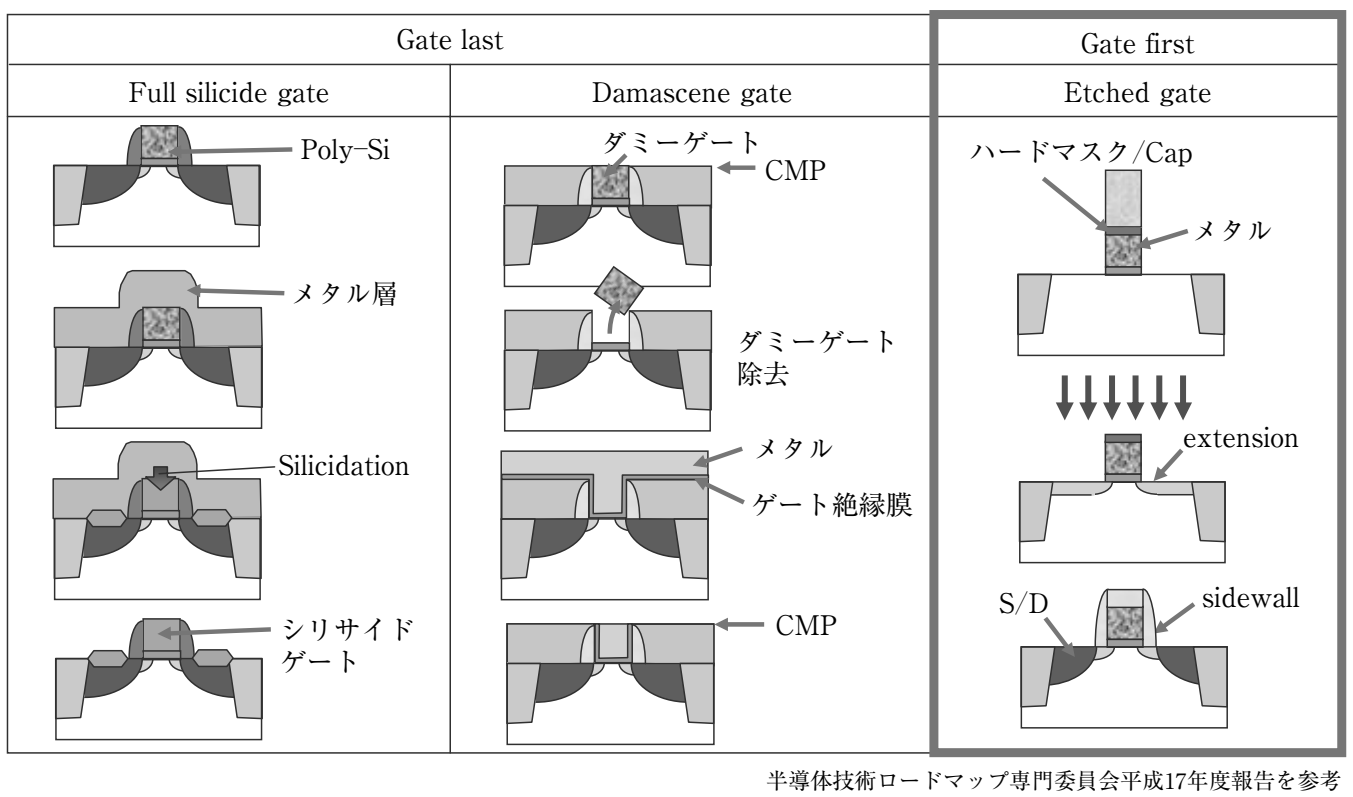

図 33 種類の High-k/Metal Gate 形成プロセス

類の High-k 絶縁膜上に形成する（Full Silicide Gate），の 4 種のゲートスタック構造が考えられる。これに加えて, 図 3 で示す形成プロセスが異なる 3 種類トランジス夕構 造があり, CMOSの形成プロセスはこれらの組合せから 選択する。このようなプロセスの選択に当っては前記の High-k 膜に対する諸要請を満たした上で，最もシンプル な CMOS 形成プロセスを選んでゆく必要がある。図 3 の トランジスタ構造の内, Gate First 構造の形成プロセスは 従来の MOSトランジスタ製造プロセスを踏襲したもので あり，今後のゲート長微細化にも対応可能な構造として開 発が期待されている方法である. 一方, Gate Last/ Damascene gate 構造は金属電極/High-k 絶縁膜界面にソ ース/ドレイン拡散層形成時の熱負荷が掛からないため,
Fermi Level Pinning 現象を回避する有望な方法であるが, 狭い空隙に複雑な電極の埋め込みを行わねばならず，将来 に向かった微細化への対応に不安がある。また Full Silicide Gate 構造は PMOS/NMOSに対する異なる Siliside 相の制御，同一チップ上にあるゲート長，幅の異なるトラ ンジスタにおける Siliside 形成の制御などにおけるプロセ ス複雑化への懸念がある.

図 4 は Gate First Dual Metal Gate/Single High-k 構造 CMOSを形成するための代表的なプロセスフローであ る $^{10)}$. PMOS 側の仕事関数を決める金属電極を付け直す ため工程数が増加すること, この付け直しの工程中に High-k 絶縁膜表面がエッチング薬液や洗浄薬液にさらさ れダメージを受ける恐れがあること, などの問題点はある 


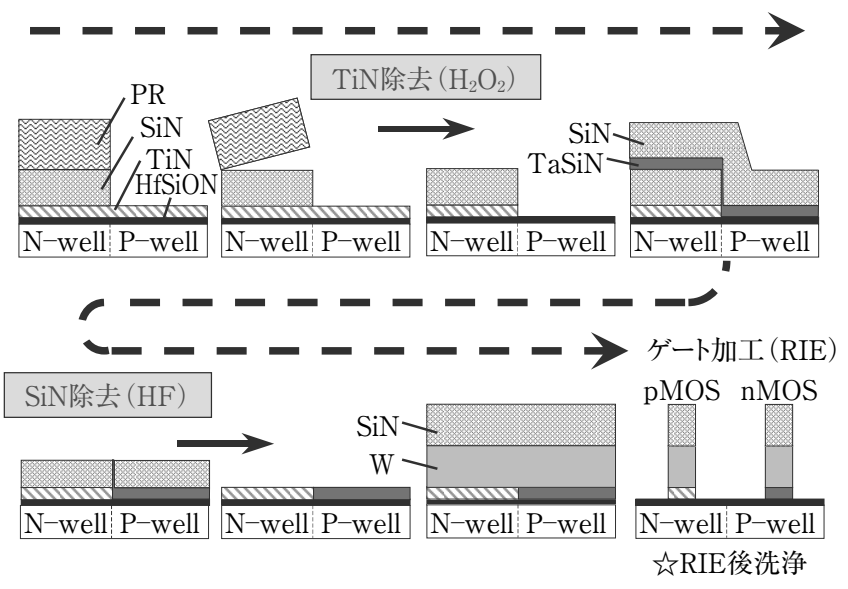

图 4 デュアルメタルゲート CMOS プロセスフロー

Poly-Si/WFM/HfSiON

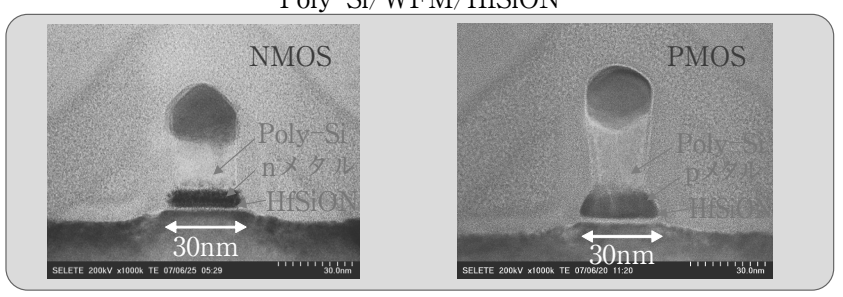

W/WFM/HfSiON

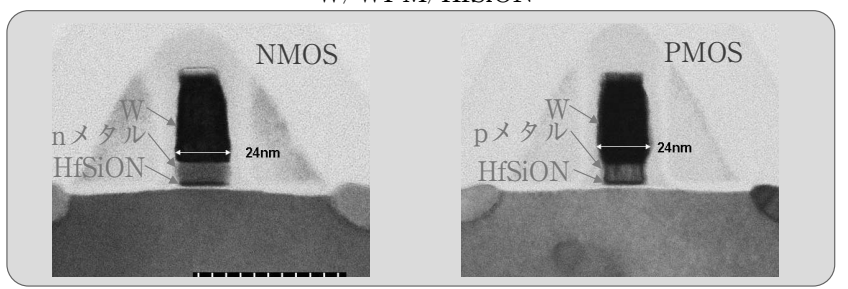

図 5 PMOS/NMOS の断面透過電子顕微鏡写真の例

が，現時点では Dual Metal Gate 構造形成のための最も現 実的な方法として提案がなされている。図 5 は同様な方 法で形成したPMOS/NMOS の断面透過電子顕微鏡写真の 例である。

一方, Single Metal Gate/Dual High-k 構造 CMOS に対 しては図 6 に示すような構造の提案がされており，Al, $\mathrm{La}, \mathrm{Mg}$ 等の元素添加によってPMOS/NMOS のシンメト リカルかつ低いVth を実現できることが示されている。 この構造の利点は，金属電極の構造が PMOS/NMOS で同 一であるために，ゲート加工の微細化がより容易になる点 にある.PMOS に対する High-k 膜への $\mathrm{Al} の$ 混入, NMOS に対する La あるいは Mg の混入は見掛け上電極の 仕事関数をそれぞれバンド端に近づける効果をもってい る。また，La や Mg は NMOS の電子移動度を向上させる 効果があることも報告されている ${ }^{11)}$ ，電子移動度に影響す

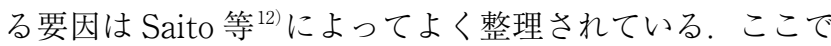
挙げられている Fixed charge, Remote-surface-roughness, Remote phonon, Phase-separation or Crystallization, Interface dipoles, Interface trap,

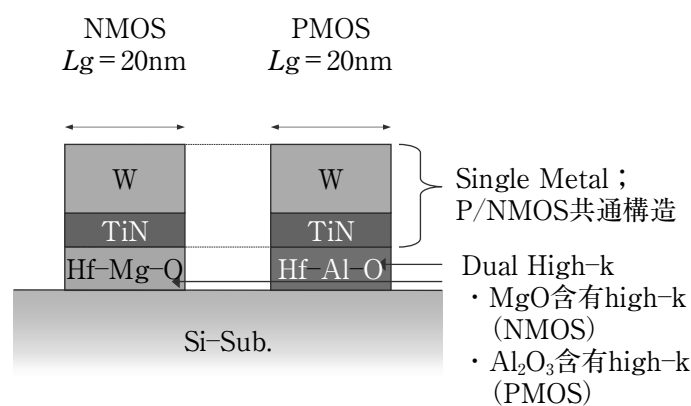

図 $6 \mathrm{Al}$ ， La， Mg 等の元素添加による PMOS/NMOS のシンメトリ カルかつ低いVthをもつ Single Metal Gate/Dual High-k 構造 $\operatorname{CMOS}$ の提案

Surface roughness 等の要因の内, Toriumi 等の報告 ${ }^{9)}$ に あるように $\mathrm{Al}, \mathrm{La}, \mathrm{Mg}$ の効果は Interface trap ないしは Interface dipoles によるものではないかと思われるが, Vth の変調と電子移動度の向上効果を統一的に説明できる 物理モデルはまだ見いだされていない，今後，このゲート スタック構造に扔けるNBTI (Negative Bias Temperature Instability) や PBTI (Positive Bias Temperature Instability）等の信頼性の十分な評価結果が 得られれば, High-k/メタルゲート CMOS デバイスの挙 動についての理解が大きく前進するものと期待される.

\section{2 ゲート絶縁膜の薄膜化}

ゲートスタック構造の選定に当たっては，High-k ゲー 卜絶縁膜の薄膜化の見通しを考慮することも重要である. ゲート絶縁膜の膜厚を議論するに際しては，従来の MOS ゲート絶縁膜に用いられてきた $\mathrm{SiO}_{2}$ の比誘電率で規格化 したEOT（Equivalent Oxide Thickness）を用いることが 多い. High-k 絶縁膜を採用するに当たっては，より高い 誘電率の材料を選び，物理的な膜厚を保ってリーク電流を 抑えながら EOTを低減する努力が払われている。しか し, Si の酸化物生成自由エネルギーが大きいために $\mathrm{Si}$ 基 板と High-k 絶縁膜の界面にはある厚さの Si 酸化層が介 在することを避けることができない，そのため，EOTの 低減はこの Si 酸化層の厚さによって下限が律則される. 翻って，この $\mathrm{Si}$ 酸化層の存在は従来の MOS デバイスが もっていた優れた界面特性を保持する役割を担っており， 優れた電気特性を得るためには不可欠な要素となってい る。したがって, EOTを低減するためには High-k 膜の 高誘電率化, 薄膜化と同時に, 界面酸化膜層の薄膜化を進 めなければならない。このとき、リーク電流の増加を抑制 すること, Vth の変動や信頼性に影響する膜中や界面の電 荷トラップ生成を抑制することが必要である。図 7 は EOTとリーク電流 Jg の関係を表しており, hp $45 \mathrm{~nm}$, $\mathrm{hp} 32 \mathrm{~nm}, \mathrm{hp} 22 \mathrm{~nm}$ に対する EOT と Jg の要求值が印印 で示してある。図中に○拉よ゙○で示したデー夕により HfSiON 膜に対して窒化のプロセスを最適化することによ り上記要求值に対応しうるゲート絶縁膜を形成できること が示されている ${ }^{13)} . \mathrm{hp} 22 \mathrm{~nm}$ 以降の技術に向けた 


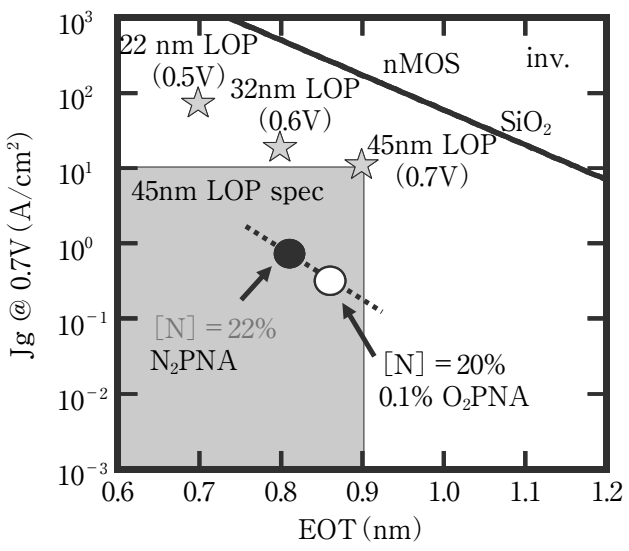

図 $7 \mathrm{HfSiON}$ 膜の $\mathrm{EOT}$ とリーク電流 Jg の関係

$\mathrm{EOT}=0.5 \mathrm{~nm}$ 以下への薄膜化は, 界面酸化膜層が存在し ない，すなわち MOSトランジスタのチャネルを構成する $\mathrm{Si}$ 基板と High $-\mathrm{k}$ 絶縁膜が $\mathrm{Si}$ 酸化層を介さずに接触する 構造の開発が必要であり, 幾つかの先駆的提案と実験結果 が報告9)されているが，上述のようなゲートスタック構造 に対する要請に応えられる技術にするためにはさらに多く の研究努力が必要である.

以上のように, High-k/メタルゲート技術はようやく実 用化に踏み出した状況にあるが, hp $45 \mathrm{~nm}$ 以降の LSI の 量産に対しては微細化，プロセス安定性，信頼性，より簡 素なプロセス・デバイスの開発，製造コスト低減など多く の改良の必要が待ち受けている.40 年以上にもわたって 使い続けられてきた従来の Poly- $\mathrm{Si} / \mathrm{SiO}_{2}$ 構造の MOS デバ イスについてもいまだに多くの未解明の部分があることを 考えても，High-k/メタルゲート技術に対してさらに多く の努力が払われるべきと思われる。

\section{3 ばらつき制御}

サブ $100 \mathrm{~nm}$ の技術世代では，トランジスタや配線など の個々の素子性能に扔けるばらつきがLSI としての性能 を律則してしまう可能性が高くなってきた。例えば SRAM では，七ル内の PMOS と NMOSのしきい值電圧 がばらつくために動作電圧 $1 \mathrm{~V}$ 以下では十分な動作領域が 取れず，LSI としての歩留を確保できないことが危惧され ている。 しきい值電圧のばらつきの原因としては，ゲート 電極加工時に㧍ける LER (Line Edge Roughness) や LWR (Line Width Roughness) 等の局所的な寸法ばらつ き，チャネルに掛かる応力のばらつき，不純物の離散的な ばらつき等が挙げられる。これまで平均化されて電気的に は見えていなかった物理パラメータのばらつきが，微細化 に伴い回路特性を左右するデバイス特性ばらつきとして顕 在化してきたといえる。このような問題に対し，回路設計 側からは製造ばらつきをあらかじめ設計に織り込む DFM (Design for Manufacturing) 技術の開発が進んでいるが, 一方で，ばらつきの物理要因の解析を通して，ばらつきに 耐性をもつプロセス・デバイスの開発の重要性が増してい る。前節までで述べたブースター技術の導入は新たなばら
つきの要因を持ち込む恐れにもつながり，High-k/メタル ゲートなどの新技術の開発にはばらつきの観点からの技術 開発が欠かせない. High-k/ゲートスタックの構造と CMOS 形成プロセスは Saito 等が挙げた移動度に影響する 各種要因に対し，ばらつきの観点からも大きく影響するこ とが懸念される。 $\mathrm{Al}$ や La 等の元素添加やシリサイドゲー 卜等，電極材料の組成を制御してVth を制御する技術に おいては, ウェハ面内のグローバルなばらつきと同時に SRAM セル内に扔けるVth マッチングのようなローカル なばらつきにも注意を払う必要がある。そのためには，ゲ 一トスタック構造内に存在する各種界面で生ずる物理現象 を十分に理解し，その現象理解に立脚したCMOS プロセ スの開発が必要である。

\section{4. まとめ}

以上述べてきた通り，エレクトロニクス産業の糧である 半導体産業にとって CMOS 微細化への努力を緩めること は許されない. $45 \mathrm{~nm}$ 以降の微細化に対し, 設計のロード マップから導かれるデバイスの性能を達成するために，プ ロセスのばらつきも含んで様々なプロセス・デバイスの物 理限界を乗り越える必要がある。事業として先端技術を開 花させるためには, CMOSの極限微細化の追求とデバイ ス・プロセスの簡素化,「ばらつき」の物理理解とプロセ スの精密制御技術，等の開発を先端開発部門から量産現場 に至るまで整合性よく，タイムリーに進める必要がある。 本稿で主に述べた High-k/メタルゲート技術も本年から製 品技術として本格的な量産の実績が積み上がっていくこと と思われるが，微細化限界の追求の中でさらに精密で高度 な技術に仕上げてゆく必要がある。

\section{参 考 文 献}

1) International Technology Roadmap for Semiconductors 2005 Edition.

2) R.H. Dennard, F.H. Gaensslen, H.-N. Yu, V.L. Rideout, E. Bassous and A. R. LeBlanc: Design of Ion-implanted MOSFET's with Very Small Physical Dimensions, IEEE Journal of Solid-State Circuits, 9 (1974) 256

3) International Technology Roadmap for Semiconductors 2005 Edition, Exective Summary, (2003) 3

4) S. Takagi, T. Mizuno, T. Tezuka, N. Sugiyama, T. Numata, K. Usuda, Y. Moriyama, S. Nakaharai, J. Koga, A. Tanabe, N. Hirashita and T. Maeda: Channel Structure Design, Fabrication and Carrier Transport Properties of Strained-Si/SiGe-on-insulator (strained-SOI) MOSFETs, Dig. of Int. Elect. Device Meeting, (2003) 3.3.1.

5) K. Goto, S. Satoh, H. Ohta, S. Fukuta, T. Yamamoto, T. Mori, Y. Tagawa, T. Sakuma, T. Saiki, Y. Shimamune, A. Katakami, A. Hatada, H. Morioka, Y. Hayami, S. Inagaki, K. Kawamura, Y. Kim, H. Kokura, N. Tamura, N. Horiguchi, M. Kojima, T. Sugii and K. Hashimoto: Technology Booster Using Strain-Enhancing Laminated SiN (SELS) for $65 \mathrm{~nm}$ Node HP MPUs, Dig. of Int. Elect. Device Meeting, (2004) 209.

6) K. Mistry, C. Allen, C. Auth, B. Beattie, D. Bergstrom, M. Bost, M. Brazier, M. Buehler, A. Cappellani, R. Chau, C.-H. Choi, G. Ding, K. Fischer, T. Ghani, R. Grover, W. Han, D. Hanken, M. Hattendorf, J. He, J. Hicks, R. Huessner, D. Ingerly, P. Jain, R. James, L. Jong, S. 
Joshi, C. Kenyon, K. Kuhn, K. Lee, H. Liu, J. Maiz, B. McIntyre, P. Moon, J. Neirynck, S. Pae, C. Parker, D. Parsons, C. Prasad, L. Pipes, M. Prince, P. Ranade, T. Reynolds, J. Sandford, L. Shifren, J. Sebastian, J. Seiple, D. Simon, S. Sivakumar, P. Smith, C. Thomas, T. Troeger, P. Vandervoorn, S. Williams and K. Zawadzki: A 45nm Logic Technology with High-k + Metal Gate Transistors, Strained Silicon, $9 \mathrm{Cu}$ Interconnect Layers, $193 \mathrm{~nm}$ Dry Patterning, and $100 \% \mathrm{~Pb}$-free Packaging, Dig. of Int. Elect. Device Meeting, (2003) 247

7) C. Hobbs, L. Fonseca, V. Dhandapani, S. Samavedam, B. Taylor, J. Grant, L. Dip, D. Triyoso, R. Hegde, D. Gilmer, R. Garcia, D. Roan, L. Lovejoy, R. Rai, L. Hebert, H. Tseng, B. White and P. Tobin : Fermi Level Pinning at the PolySi/Metal Oxide Interface, Symposia on VLSI Technology Dig., (2003) 9.

8) K. Shiraishi, K. Yamada, K. Torii, Y. Akasaka, K. Nakajima, M. Kohno, T. Chikyo, H. Kitajima and T. Arikado : Physics in Fermi Level Pinning at the PolySi/Hf-based High-k Oxide Interface, Symposia on VLSI Technology Dig., (2004) 108.

9) A. Toriumi, K. Kita, K. Tomida, Y. Zhao, J. Widiez, T. Nabatame,
H. Ota and M. Hirose: Materials Science-based Device Performance Engineering for Metal Gate High-k CMOS, IEDM '07 Technical Digest., (2007) 53.

10) F. Ootsuka, Y. Tamura, Y. Akasaka, S. Inumiya, H. Nakata, M. Ohtsuka, T. Watanabe, M Kitajima, Y. Nara and K. Nakamura: Full-Metal-Gate Integr Ation of Dual-Metal-Gate HfSiON CMOS Tr Ansistors by Using Oxidation-Free Dummy-Mask Process, Ext. Abst. of the 2006 Int. Conf. on Solid State Devices and Materials, (2006) 1116.

11) N. Mise, T. Morooka, T. Eimori, S. Kamiyama, K. Murayama, M. Sato, T. Ono, Y. Nara and Y. Ohji : Single Metal/Dual High-k Gate Stack with Low Vth and Precise Gate Profile Control for Highly Manufacturable Aggressively Scaled CMISFETs, Dig. of Int. Elect. Device Meeting, (2007) 527.

12) S. Saito, D. Hisamoto, S. Kimura and M. Hiratani : Unified Mobility Model for High-lc Gate Stacks, IEDM '03 Technical Digest., (2003) 33.3.1.

13) Y. Nara, F. Ootsuka, S. Inumiya and Y. Ohji : High-k/Metal Gate Stack Technology for Advanced CMOS, 8th ICMICT, (2006) 360. 